\title{
Ecophysiological interpretation of oxygen consumption rates and enzymatic activities of deep-sea copepods
}

\author{
Erik V. Thuesen ${ }^{1, *}$, Charles B. Miller ${ }^{2}$, James J. Childress ${ }^{1}$ \\ ${ }^{1}$ Marine Science Institute, University of California, Santa Barbara, California 93106, USA \\ ${ }^{2}$ College of Oceanic and Atmospheric Sciences, Oregon State University, Corvallis, Oregon 97331, USA
}

\begin{abstract}
We measured oxygen consumption rates, the activities of citrate synthase (CS) and lactate dehydrogenase (LDH) and protein contents for over 30 species of deep-sea pelagic Copepoda. The lowest oxygen consumption rates were measured in Euaugaptilus magnus and the highest rates were measured in Paraeuchaeta tonsa. Weight-specific oxygen consumption rates declined significantly with increasing size of the organism. None of the biochemical parameters were particularly good predictors of metabolic rate. Although linear regressions of LDH activity and protein content against oxygen consumption were statistically significant, $R^{2}$ values for the relationships were very low. CS activity was not significantly correlated with metabolic rate. The highest CS activities were measured in Pleuromamma abdominalis and Calanus pacificus, which were the 2 smallest and shallowest-living species in our investigation. The lowest CS activities were measured in Euaugaptilus antarcticus and Pachyptilus pacificus. Disseta scopularis had the highest LDH activities and Onchocalanus magnus had the lowest LDH activities. Over all specimens, there were statistically significant increases in weight-specific activities of CS and LDH as a function of body mass. There was much greater variation in glycolytıc potential as indicated by LDH activity than in CS activities. Epipelagic copepods apparently rely less on glycolytic energy sources than do mesopelagic and bathypelagic copepods. Higher LDH activities of larger Copepoda may indicate a greater dependence on LDH for burst swimming in large species compared with smaller ones or a reliance on glycolytic abilities for sustained swimming during vertical migrations. Our enzyme data do not support the suggestion that high LDH activities are adaptations to the very low oxygen concentrations found in the oxygen minimum layer. Enzymatic ratios were used to interpret lifestyle, and deep-sea copepods fell into 3 metabolic groups, 'muscular sinkers', 'thinmuscled floaters' and 'giants', that were related to morphological pattern and behaviour. The effect of hydrostatic pressure on the metabolic rate of an undescribed, but very common, species of Megacalanus was investigated and found to be non-significant. Copepods do not display the depth-related declines in metabolic rates that are found in shrimps, fishes and cephalopods
\end{abstract}

KEY WORDS: Citrate synthase Crustacea Deep sea $\cdot$ Lactate dehydrogenase $\cdot$ Copepoda $\cdot$ Respiration - Zooplankton - Enzyme activity

\section{INTRODUCTION}

Copepods are usually the most abundant type of metazoan in the pelagic realm of the oceans, and midwater copepods play an important role in the cycling of organic matter in the oceans. It is necessary to increase our knowledge of the metabolic potential of copepods

\footnotetext{
- Present address: Evergreen State College, Lab II, Olympia, Washington 98505 , USA.

E-mail: thuesene@elwha.evergreen.edu
}

in order to calculate their importance in the biological carbon pump in the marine environment (Angel 1989, Longhurst et al. 1990. Childress \& Thuesen 1992). In order to estimate the potential for large midwater copepods to transform organic carbon into inorganic carbon, we must first investigate their metabolic rates. Although much is known concerning the biology and ecology of shallow-living copepods, there have been few studies of physiological and biochemical aspects of deep-sea Copepoda. Most studies of large meso- and bathypelagic copepods have been focused on questions 
concerning taxonomy and distribution. A few studies have looked at chemical compositions of deep-sea copepods (Lee et al. 1971, Childress \& Nygaard 1974 Lee \& Barnes 1975), and some studies have investigated the metabolic physiology of deep-living species (Childress 1971, 1977, Champalbert \& Gaudy 1972, Childress Gaudy 1975). These investigations have looked at only a few deep-sea species and usually not more than a few individuals of the very large species.

The most extensive study of deep-sea copepod metabolic physiology was undertaken by Childress (1977) and was on the synergistic effects of hydrostatic pressure, temperature and oxygen concentration on the oxygen consumption rate of the mesopelagic species Gaussia princeps. No significant changes in the metabolic rate of this metridinid copepod were observed between hydrostatic pressures of 1 and 61 atm, although there were some significant differences between intermediate pressures, demonstrating the complex nature of pressure effects. G. princeps displayed more or less normal physiological responses to temperature changes $\left(Q_{10} S\right.$ of 1.3 to 2.6$)$ with greater temperature effects at lower temperatures and higher pressures. Furthermore, Childress found that $G$. princeps cannot regulate its oxygen consumption to the low oxygen concentrations found in its environment off California, but it can survive for over $10 \mathrm{~h}$ under anoxic conditions.

In our current study, we measured oxygen consumption rates of deep-sea copepods and measured metabolic enzyme activities (citrate synthase and lactate dehydrogenase) and protein contents on the same individuals with the goal of developing biochemical indices that can predict metabolic rates. We examined physiological and biochemical parameters with regard to body size and compared the amounts of glycolytic enzyme activity (as an index of burst swimming capacity) and aerobic enzyme activity in order to assess the roles of these 2 parameters in the lives of these copepods. We also carried out studies on the effects of temperature and hydrostatic pressure on the metabolic rates of some selected deep-sea species. Oxygen consumption rates of visually-orienting crustaceans off California (USA) decline rapidly with increasing habitat depth (Childress 1975), and we compared our copepod data with the earlier crustacean data as a test of the visual interactions hypothesis. This hypothesis states that selection for higher metabolic rates is reduced in organisms that are not involved visually in predator-pre interactions (see review by Childress 1995). The visual interactions hypothesis therefore predicts that deep-sea copepods will have metabolic rates similar to shallow-living copepods after accounting for size and temperature effects. The lifestyle of any deep-sea organism is difficult to unravel, but through investigations of their biochemistry and physiology, we can better understand the roles that deepsea copepods play in the oceanic ecosystem.

\section{METHODS}

Copepod specimens. Copepods were collected using an opening-closing Mother Tucker trawl with a $10 \mathrm{~m}^{2}$ mouth fitted with a $30 \mathrm{I}$ insulated cod end (Childress et al. 1978). This cod end ensures that deep-living animals are protected from elevated temperatures during recovery at the surface and also minimizes physical damage due to water turbulence. Midwater trawling was carried out off Point Conception, California, USA $\left(123^{\circ} \mathrm{E}, 34^{\circ} 50^{\prime} \mathrm{N}\right)$, during cruises of the RV 'Point Sur' in June and September 1992. This is a highly productive area in the California Current system, and oxygen levels can be as low as $6 \mathrm{~mm} \mathrm{Hg}$ in the heart of the midwater oxygen minimum layer $(\sim 800 \mathrm{~m})$. Ship speed was held below 1 knot during trawling to keep turbulence in the net low and decrease the biomass in the cod end. Although we sampled all depth ranges from the surface to $3.4 \mathrm{~km}$, most copepod specimens came from above $2 \mathrm{~km}$. Most trawls were carried out horizontally within a narrow depth range. Upon recovery, animals were transferred to $5^{\circ} \mathrm{C}$ seawater and held at $5^{\circ} \mathrm{C}$ until they were identified and used for metabolic rate measurements. Large deep-sea copepods are brightly and characteristically colored, with distinctive shapes and swimming patterns. We used these features to sort many individuals of each species using ladles and wide-bore pipettes. Working names were assigned to each sorted type, and voucher specimens were preserved in formaldehyde for later identification ashore. Identifications were confirmed in most cases by outstanding experts on the genera found. Specimens for enzyme assays were frozen in liquid nitrogen aboard ship. Some of these frozen specimens were Iater transported on dry ice and then kept in $\mathrm{a}-70^{\circ} \mathrm{C}$ freezer for up to $6 \mathrm{mo}$.

Oxygen consumption measurements. Oxygen consumption rate measurements on board ship started within $24 \mathrm{~h}$ following collection. Only specimens collected in excellent condition were used. Copepods were transferred to appropriate size glass syringes ( 5 to $50 \mathrm{ml}$ ) that were used as miniature respiration chambers (Thuesen \& Childress 1993a, b). Syringes contained filtered seawater $(0.20 \mu \mathrm{m}$ membrane filter $)$ with $50 \mathrm{mg} \mathrm{l}^{-1}$ of streptomycin, and copepods were incubated at $1.5,5.0$ or $10.0^{\circ} \mathrm{C}$. Water samples were withdrawn periodically from the incubation syringe through a 3 -way valve with a gas-tight syringe and the new incubation volume was recorded. Before withdrawal of the sample, syringes were turned end-over- 
end several times to thoroughly mix the water. Oxygen, nitrogen and carbon dioxide contents were measured with a gas chromatograph (Childress et al. 1984). Incubation periods were usually $\sim 24 \mathrm{~h}$. Control syringes containing only filtered seawater and streptomycin were run simultaneously. After removal of the copepod, experiments were periodically left to continue as controls to check for bacterial contamination. Background respiration was always undetectable at 1.5 and $5^{\circ} \mathrm{C}$. Some experiments were carried out at a hydrostatic pressure of 101 atm following methods previously described (Childress \& Thuesen 1993). All other oxygen consumption measurements were made at atmospheric pressure. Following completion of experiments, animals were weighed at sea using a motion compensated shipboard precision balance system (Childress \& Mickel 1980 ) before being frozen in liquid nitrogen for later enzymatic analyses.

Enzyme activity measurements. Citrate synthase (CS, EC 4.1.3.7), an important regulatory enzyme that functions in the first step of the citric acid cycle, was selected as an indicator of aerobic metabolic potential. Lactate dehydrogenase ( $\mathrm{LDH}, \mathrm{EC}$ 1.1.1.27), the terminal enzyme in glycolysis that contributes to both aerobic and anaerobic metabolic pathways, was selected as an indicator of glycolytic potential. CS and LDH activities in fish muscle have both been found to correlate well with oxygen consumption rates (Childress \& Somero 1979, Sullivan \& Somero 1980, Torres \& Somero 1988, Somero \& Childress 1990). In invertebrates, CS and LDH may or may not correlate well with oxygen consumption rates (Berges \& Ballantyne 1991, Childress \& Thuesen 1992, Berges et al. 1993, Thuesen \& Childress 1993a, b, 1994).

Whole copepods were weighed on a Mettler analytical balance while still frozen and homogenized using Duall hand held glass homogenizers kept on ice. Homogenization dilutions ranged from $1: 29$ to $1: 1999$ parts weight to volume of $0.01 \mathrm{M}$ tris homogenization buffer, $\mathrm{pH} 7.5$ at $10^{\circ} \mathrm{C}$. Very high dilutions were necessary for some species to reduce the high $\mathrm{LDH}$ activities in the cuvettes so that substrate levels would not become limiting during the assay. Aliquots of homogenate were transferred to microfuge tubes and centrifuged at $6600 \times g$ for $10 \mathrm{~min}$ at $5^{\circ} \mathrm{C}$. All assays were performed within $1 \mathrm{~h}$ of homogenization using a Hewlett-Packard diade array spectrophotometer equipped with a water-jacketed cuvette holder. Measurements of enzyme activity were made in $2 \mathrm{ml}$ quartz cuvettes at $20^{\circ} \mathrm{C}$ under non-limiting conditions in order to estimate maximum metabolic potential following procedures described previously (Childress \& Somero 1979, Somero \& Childress 1980). Enzyme activities are expressed as units ( $\mu$ moles of substrate converted to product per minute) per gram wet weight of copepod.
Activity measurements of CS were performed in a medium containing $50 \mathrm{mM}$ imidazole/ $\mathrm{HCl}$ buffer $(\mathrm{pH}$ 7.8 at $\left.20^{\circ} \mathrm{C}\right), 0.5 \mathrm{mM}$ oxaloacetate, $0.1 \mathrm{mM}$ acetyl-CoA, $0.1 \mathrm{mM} 5,5$-dithiobis (2-nitrobenzoic acid) (DTNB) and $1.5 \mathrm{mM} \mathrm{MgCl}_{2}$. The increase in absorbance at $412 \mathrm{~nm}$ due to the reaction of the reduced coenzyme A generated by the enzymatic reaction with DTNB was recorded. We recorded background activity after the addition of homogenate supernatant, and this background rate was subtracted from the overall rate after the assay reaction was initiated by addition of the oxaloacetate to arrive at the enzyme activity of the sample. LDH activity measurements were performed in a medium containing $80 \mathrm{mM}$ tris/ $\mathrm{HCl}$ buffer $(\mathrm{pH} 7.2$ at $20^{\circ} \mathrm{C}$ ) $2 \mathrm{mM}$ sodium pyruvate, $150 \mu \mathrm{M} \mathrm{NADH}$, and $100 \mathrm{mM} \mathrm{KCl}$. LDH assay reactions were started by addition of the sample supernatant, and the decrease in absorbance at $340 \mathrm{~nm}$ due to $\mathrm{NADH}$ oxidation was recorded. Aliquots of crude homogenate were assayed for total protein content using the Lowry method (Lowry et al. 1951)

Statistical analysis. All statistical analyses were performed with the Statview II computer program (Abacus Concepts Inc, Berkeley, CA). Simple linear regressions were carried out on ln-transformed data to improve linearity and maintain consistency with previous studies. Oxygen consumption rates, protein contents and enzymatic activities of copepods were evaluated in relation to wet mass of the animals, and scaling coefficients were derived from the wellknown allometric equation $y=a M^{b}$, where $M$ is the wet weight of the animal, $b$ is the scaling coefficient, and $a$ is a constant. Wet mass was chosen as a measure of size, because this is the parameter of physiological significance determining constraints on swimming, predation, etc. Oxygen consumption rates of copepods were also investigated in relation to habitat depth. Minimum recorded capture depth was the variable used to describe habitat depth rather than minimum depth of occurrence (Childress 1995) since there is insufficient information regarding the depth distribution of these copepods. Recorded capture depths usually represented only the depths at which our experimental specimens were collected, however these were supplemented by additional capture data if available. For comparisons with the deep-living species in our study, metabolic rates of shallow-living copepods (Champalbert \& Gaudy 1972, Gaudy 1975) were adjusted using a $Q_{10}$ of 2.0 to account for effects of temperature and size-adjusted to a standard wet weight of $10 \mathrm{mg}$ using the scaling coefficient, $b$, of -0.214 that was calculated from our specific metabolic rate data. A wet weight of $10 \mathrm{mg}$ is at the lower end of the weight range of copepods in our study. 
Table 1 Wet weight, minimum capture depth, mean oxygen consumption, mean enzyme activity and mean protein content of deep-sea calanoid copepods. Rates are expressed relative to wet weight. The number of specimens ( $\mathrm{n}$ ) for the enzyme activity and protein content columns is the same as that for the preceding oxygen consumption value unless specified. $Q_{10}$ values are always given (in italics) with respect to oxygen consumption rates measured at $5^{\circ} \mathrm{C}$ and $1 \mathrm{~atm}$. Temperatures are given for oxygen consumption measurements. All enzymatic activities were measured at $20^{\circ} \mathrm{C}$. Some megacalanid metabolic rates were measured at 101. atm as noted. na: not assayed, nd: not detected, nr: not recorded, ns: not significant

\begin{tabular}{|c|c|c|c|c|c|c|c|}
\hline \multirow{2}{*}{$\begin{array}{l}\text { Superfamily } \\
\text { Family } \\
\text { Genus and species }\end{array}$} & \multirow[t]{2}{*}{$\begin{array}{l}\text { Wet weight } \\
\text { (range, g) }\end{array}$} & \multirow{2}{*}{$\begin{array}{l}\text { Minumum } \\
\text { capture } \\
\text { depth (m) }\end{array}$} & \multirow{2}{*}{${ }^{\mathrm{T}}$} & \multirow{2}{*}{$\begin{array}{l}\text { Mean oxygen } \\
\text { consumption } \\
\left(\mu \text { mol } \mathrm{O}_{2} \mathrm{~g}^{-1} \mathrm{~h}^{-1}\right) \\
\pm \mathrm{SE}(\mathrm{n}\}, Q_{1}\end{array}$} & \multicolumn{2}{|c|}{$\begin{array}{c}\text { Mean enzyme activity } \\
\pm \operatorname{SE}(\mathrm{n})\end{array}$} & \multirow{2}{*}{$\begin{array}{l}\text { Protein content } \\
(\% \text { wet weight) } \\
\quad \pm S E(n)\end{array}$} \\
\hline & & & & & $\begin{array}{c}\mathrm{CS} \\
\text { (units } \mathrm{g}^{-1} \text { ) }\end{array}$ & $\begin{array}{c}\text { LDH } \\
\text { (units } g^{-1} \text { ) }\end{array}$ & \\
\hline \multicolumn{8}{|l|}{ Augaptiloidea } \\
\hline \multicolumn{8}{|l|}{ Arietellidae } \\
\hline Arietellus cf. plumifer & $0.0081-0.0112$ & 200 & 5.0 & $1.769 \pm 0.297(4)$ & $3.478 \pm 0.211$ & $12.093 \pm 4.257$ & $4.90(1)$ \\
\hline \multicolumn{8}{|l|}{ Augauptilidae } \\
\hline Euaugaptilus antarcticus & $0.0187-0.0270$ & 450 & 5.0 & $1.028 \pm 0.144(6)$ & $0.378 \pm 0.022$ & $29.831 \pm 2.585$ & $0.99 \pm 0.09$ \\
\hline Euaugaptilus magnus & $0.0248-0.0385$ & 450 & 5.0 & $0.575 \pm 0.116(9)$ & $0.882 \pm 0.217$ & $45.881 \pm 5.266$ & $2.20 \pm 0.35(6)$ \\
\hline Euaugaptilus nodifrons & 0.0597 & 450 & 5.0 & $0.563(1)$ & 0.790 & 21.966 & 0.97 \\
\hline Pachyptilus pacificus & $\begin{array}{l}0.0134-0.0186 \\
0.0134-0.0186\end{array}$ & 450 & $\begin{array}{l}5.0 \\
1.5\end{array}$ & $\begin{array}{l}1.394 \pm 0.151(6) \\
1.256 \pm 0.102(4) \mathrm{ns}\end{array}$ & $0.441 \pm 0.077(9)$ & $11.947 \pm 3.795$ & $3.01 \pm 0.77(7)$ \\
\hline \multicolumn{8}{|l|}{ Heterorhabdidae } \\
\hline Disseta grandis & $0.0101-0.0129$ & 670 & 5.0 & $1.392 \pm 0.149(9)$ & $0.967 \pm 0.049$ & $19.181 \pm 1.828$ & $2.71 \pm 0.22(2)$ \\
\hline Disseta scopulans & $\begin{array}{l}0.0188-0.0202 \\
0.0240-0.0275\end{array}$ & 540 & $\begin{array}{l}5.0 \\
1.5\end{array}$ & $\begin{array}{l}0.665 \pm 0.072(7) \\
1.095 \pm 0.082(2), 4.2\end{array}$ & $1.596 \pm 0.200(9)$ & $70.027 \pm 3.575$ & $2.66 \pm 0.34(6)$ \\
\hline Hernirhabdus grimaldij & 0.0382 & n.r & 5.0 & $0.509(1)$ & na & na & na \\
\hline Lucicitiidae & & & & & & & \\
\hline Lucicutia bicornuta & $0.0072-0.0152$ & 450 & 5.0 & $1.103 \pm 0.141(6)$ & $0.479 \pm 0.093(4)$ & $9.781 \pm 0.860$ & $2.39 \pm 0.65(2)$ \\
\hline Lucicutra maxima & $0.0084-0.016 .5$ & 610 & 5.0 & $1.400 \pm 0.162(4)$ & $0.747 \pm 0.075$ & $14.477 \pm 1.668$ & $2.23 \pm 0.21(11)$ \\
\hline & $0.0131-0.0165$ & & 1.5 & $1.183 \pm 0.229(5) \mathrm{ns}$ & & & \\
\hline & $0.0084-0.0130$ & & 10.0 & $2.767 \pm 0.314(2) .3 .9$ & & & \\
\hline Euchirella bitumida & $0.0069-0.0129$ & 350 & 5.0 & $2.404 \pm 0.305(7)$ & $1.844 \pm 0.348(6)$ & $6.080 \pm 0.846$ & $7.52 \pm 0.40(4)$ \\
\hline & $0.0127-0.01 .29$ & & 1.5 & $2.233 \pm 0.015(2) \mathrm{ns}$ & & & \\
\hline Euchirella maxıma & $0.0183-0.0194$ & 350 & 5.0 & $2.031 \pm 0.035$ & $1.321 \pm 0.644$ & $2.143 \pm 1.076$ & $5.50 \pm 0.38$ \\
\hline Pseudochirella polyspina & $0.0086-0.0159$ & 1000 & 5.0 & $1.716 \pm 0.167(6)$ & $1.764 \pm 0.081$ & $0.707 \pm 0.220$ & $6.15 \pm 0.82(2)$ \\
\hline Metridinidae & & & & & & & \\
\hline Gaussia princeps & $0.0327-0.0387$ & 400 & 5.0 & $1.923 \pm 0.121(6)$ & $2.408+0.175(8)$ & $1.899 \pm 0.285$ & $2.67 \pm 0.23(7)$ \\
\hline G. princeps (males) & $0.0317-0.0378$ & 400 & 5.0 & $2.070 \pm 0.204(10)$ & $2.052 \pm 0.160$ & $9.811 \pm 1.034(8)$ & $1.81 \pm 0.39(5)$ \\
\hline Metridia princeps & $0.0068-0.0181$ & 550 & 5.0 & $1.622 \pm 0.481(5)$ & $1.073 \pm 0.184(8\}$ & $3.886 \pm 0.666(9)$ & $2.83 \pm 0.71(4)$ \\
\hline & $0.0086-0.0181$ & & 1.5 & $2.047 \pm 0.532(4) \mathrm{ns}$ & & & \\
\hline Pleuromamma abdominalis & $0.0020-0.0021$ & 350 & & na & $4.034 \pm 0.368(2)$ & $0.887 \pm 0.241$ & na \\
\hline Clausocalanoidea & & & & & & & \\
\hline Aetideidae & & & & & & & \\
\hline Gaetanus antarcticus & $\begin{array}{l}0.0214-0.0308 \\
0.0240-0.0275\end{array}$ & 600 & $\begin{array}{l}5.0 \\
1.5\end{array}$ & $\begin{array}{l}1.260 \pm 0.114(10) \\
0.723 \pm 0.101(3), 4.9\end{array}$ & $1.480 \pm 0.071(15)$ & $0.315+0.058$ & $2.67 \pm 0.44(9)$ \\
\hline Gaetanus kruppi & 0.0072 & 540 & 5.0 & $1.380(1)$ & 1.162 & 0.394 & 9.18 \\
\hline Gaetanus pileatus & $0.0082-0.0089$ & 350 & 5.0 & $4.284 \pm 0.081(3)$ & $1.895 \pm 0.190$ & $0.326 \pm 0.033$ & $1.47 \pm 0.45(2)$ \\
\hline Euchaetidae & & & & & & & \\
\hline Paraeuchaeta birostrata & $\begin{array}{l}0.0109-0.0146 \\
0.0116-0.0143\end{array}$ & 400 & $\begin{array}{r}5.0 \\
10.0\end{array}$ & $\begin{array}{l}2.326 \pm 0.102(11) \\
2.899 \pm 0.219(8), 1.6\end{array}$ & $0.737 \pm 0.102(1 \varepsilon)$ & $1.178 \pm 0.095$ & $5.45 \pm 0.43(11)$ \\
\hline Paraeuchaeta californica & $0.0136-0.0139$ & 375 & 5.0 & $2.420 \pm 0.226(3)$ & $0.803 \pm 0.068$ & $1.414 \pm 0.300$ & $3.41 \pm 0.38$ \\
\hline Paraeuchaeta rubra & $0.0117-0.0138$ & 400 & 5.0 & $1.700 \pm 0.111$ & $0.711 \pm 0.117(3)$ & $1.019 \pm 0.17 \mathrm{t}$ & $3.35 \pm 0.59$ \\
\hline Paraeuchaeta sesquipedalıs & $0.0236-0.0262$ & 1350 & 5.0 & $2.046 \pm 0.121(4)$ & nd & $0.611 \pm 0.107$ & nà \\
\hline Paraeuchaetatonsa & $0.0062-0.0070$ & 260 & 5.0 & $4.344 \pm 0.273(3)$ & $1.187 \pm 0.062$ & $1.071 \pm 0149$ & na \\
\hline Pseudeuchaeta brevicauda & $0.0250-0.0278$ & 440 & 5.0 & $1.832 \pm 0.145(2)$ & $0.896 \pm 0.713$ & $0.509 \pm 0.234$ & $2.86(1)$ \\
\hline Valdiviella olugarthra & $0.0150-0.0252$ & 1060 & 5.0 & $1.512 \pm 0.423(3)$ & $1.404 \pm 0.123$ & $1.145 \pm 0126$ & $4.64 \pm 1.10$ \\
\hline Phaennidae & & & & & & & \\
\hline Onchocalanus magnus & $0.0089-0.0174$ & 260 & 5.0 & $3.375 \pm 0.197(5)$ & $1.025 \pm 0.644(3)$ & $0.086 \pm 0.006$ & $5.94\{1\}$ \\
\hline Scolecithrucidae & & & & & & & \\
\hline Landrumius gigas & $0.0253-0.0377$ & 460 & 5.0 & $2.284 \pm 0.851(2)$ & $1.092(1)$ & 1.466 & 1.61 \\
\hline Megacalanoidea & & & & & & & \\
\hline Calanidae & & & & & & & \\
\hline Calanus pacificus & 0.0009 & 10 & & na & $5.947(1)$ & 2.059 & na \\
\hline Megacalanidae & & & & & & & \\
\hline Bathycalanus bradyi & $0.0356-0.0865$ & 1350 & 5.0 & $1.637 \pm 0.130(9)$ & $2.484 \pm 0.182(14)$ & $33.759 \pm 4.342$ & $1.59 \pm 0.45(5)$ \\
\hline at $101 \mathrm{~atm}$ & $0.0731-0.0781$ & & 5.0 & $1.482 \pm 0.329(2)$ & & & \\
\hline at $101 \mathrm{~atm}$ & $0.0377-0.0746$ & & 1.5 & $1.688 \pm 0.412(3) \mathrm{ns}$ & & & \\
\hline Bathycalanus nchardi & $0.0253-0.0572$ & 900 & 5.0 & $1.471(1)$ & $2.366 \pm 0.238(7)$ & $14.720 \pm 0.855$ & $2.17 \pm 0.73(5)$ \\
\hline at $101 \mathrm{~atm}$ & $0.0548-0.0572$ & & 5.0 & $1.070 \pm 0.050$ & & & \\
\hline & $0.0253-0.0562$ & & 1.5 & $1.877 \pm 0.470(3), 5.0$ & & & \\
\hline Bathycalanussp. A & 0.0572 & $\mathrm{nr}$ & 5.0 & $1.637(1)$ & 1.979 & 15.161 & 2.108 \\
\hline Megacalanus pnnceps & $0.0429-0.0720$ & 350 & 5.0 & $1.651=0.149\{6\}$ & $2.762 \pm 0.293$ & $20.010 \pm 6.079$ & $1.82 \pm 0.05(2)$ \\
\hline Megacalanus sp. A & $0.0312-0.0391$ & 400 & 5.0 & $1.767 \pm 0.179|7\rangle$ & $2.306 \pm 0.052(29)$ & $1.250 \pm 0.111$ & $2.54 \pm 0.16(22)$ \\
\hline at $101 \mathrm{~atm}$ & 0.0345 & & 5.0 & $1.495(1)$ & & & \\
\hline & $0.0325-0.0390$ & & 1.5 & $1.445 \pm 0.071(7) .1 .8$ & & & \\
\hline at $101 \mathrm{~atm}$ & $0.0330-0.0360$ & & 1.5 & $1.685 \pm 0.147 .51 \mathrm{~ns}$ & & & \\
\hline & $0.0308-0.0345$ & & 100 & $3.755 \pm 0.143(6) .4 .5$ & & & \\
\hline Megacalanus sp. B & 0.0372 & $\mathrm{nr}$ & 5.0 & $1.285(1)$ & 2.718 & 8.554 & na \\
\hline
\end{tabular}




\section{RESULTS}

Many specimens of large mesopelagic and bathypelagic Copepoda were collected in excellent condition using the Mother Tucker trawl at low ship speeds. Species that have extremely long antennae or other delicate appendages were often captured in excellent condition and could be kept alive at $5^{\circ} \mathrm{C}$ for many days on board ship in 11 containers. Wet weights, oxygen consumption rates, activities of CS and LDH, and protein contents are reported in Table 1

\section{Oxygen consumption rates}

We were able to perform successful oxygen consumption measurements at $5^{\circ} \mathrm{C}$ on 216 specimens of 33 species of large deep-sea copepods (Table 1). Most specimens were still in excellent condition at the end of the experimental period. However, using syringes as respirometer chambers was not a very successful technique for smaller copepods (e.g. Calanus pacificus) since they tended to introduce themselves into the needle aperture and perish, evidently due to lack of oxygen. Except for some male individuals of Gaussia princeps, all our measurements were made on female specimens. The lowest oxygen consumption rates were measured in Euaugaptilus magnus and the highest rates were measured in Paraeuchaeta tonsa. For all species, oxygen consumption rates showed a decline with increasing size of the specimens (Fig. 1, Table 2). Although size ranges within a species were generally too narrow for observation of size-related physiological changes, analyses of copepods by families show that closely related species generally show the trend of lower oxygen consumption rates with increasing species size. Statistical analyses of metabolic declines with increasing wet weight were significant when taxonomically similar species were analyzed as discrete groups, and the Euchaetidae and Augauptilidae showed significant declines in metabolic rate with increasing body mass (Fig. 2A, B, Table 2). Many copepod families showed no significant relationship between mass-specific oxygen consumption rate and body mass over the size range of the specimens.

Oxygen consumption rates for 9 species were also measured at $1.5^{\circ} \mathrm{C}$ and 3 species were measured at $10^{\circ} \mathrm{C}$ (Table 1). Temperature had vanous effects on oxygen consumption rates. Six of the $Q_{10}$ s for the $1.5^{\circ} \mathrm{C}$ measurement were non-significant and the highest was 5.0 (Table 1 ). The $Q_{10}$ s for the $10^{\circ} \mathrm{C}$ measurements ranged from 1.6 to 4.5. An undescribed species of Megacalanidae, Megacalanus sp. A, was one of the most common, robust copepods collected during our investigation, and we measured its oxygen consumption at both atmospheric pressure and $101 \mathrm{~atm}$ $(=1000 \mathrm{~m}$ depth). There was no significant difference in the oxygen consumption rate of this species between the 2 pressures (2-tailed $t$-test, $t=1.612, \mathrm{p}=0.138$; Fig. 3A) . Bathycalanus bradyi and Bathycalanus richardi also showed no noticeable differences in their oxygen consumption rates between the 2 pressures (Fig. 3B).

\section{Enzymatic activities}

Citrate synthase and lactate dehydrogenase activities were measured for 34 species of copepods (Table 1). We were not able to detect CS activity in Paraeuchaeta sesquipedalis. The highest CS activities were measured in Pleuromamma abdominalis and Calanus pacificus, which were the 2 smallest and shallowest-living species in our investigation. The lowest CS activities were found in the augauptilids Euaugaptilus antarcticus and Pachyptilus pacificus. Disseta scopularis had the highest LDH activities and Onchocalanus magnus had the lowest LDH activities. Over all specimens, there were statistically significant increases in weight-specific activities of CS and LDH as a function of body mass (Fig. 4). There was much greater variation in glycolytic potential as indicated by LDH activity than in aerobic potential. Across all species, mean CS activities ranged from 0.378 to

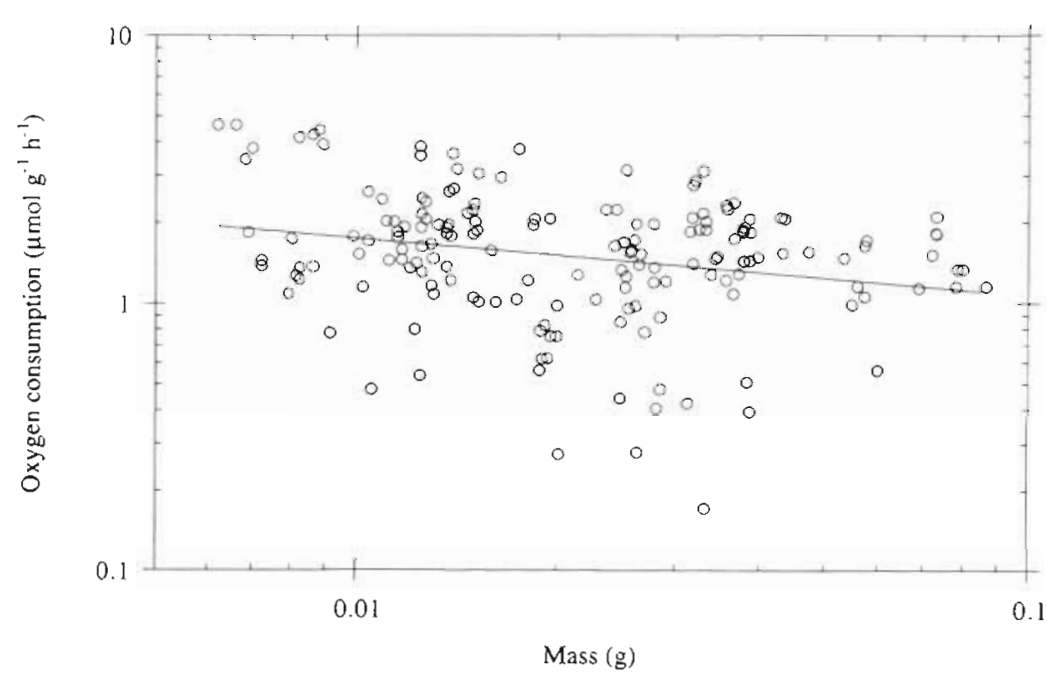

Fig. 1. Relationship between body size ( $g$ wet weight) and mass-specific oxygen consumption rate $\left(\mu \mathrm{mol} \mathrm{O}_{2} \mathrm{~g}^{-1}\right.$ wet weight $\left.\mathrm{h}^{-1}\right)$ at $5^{\circ} \mathrm{C}$ for deep-sea pelagic copepods (all individuals of all species). The equation of the regression line is $y=0.656 x^{-0.214}, R=0.331, p<0.002$ 
Table 2. Allometric scaling relationships of oxygen consumption rates, enzymatic activities and protein contents of Copepoda from off California. Only regressions with slopes significantly different from zero are listed. $\mathrm{n}=$ number of specimens

\begin{tabular}{|c|c|c|c|c|}
\hline \multirow{2}{*}{$\begin{array}{l}\text { Metabolic parameter } \\
\text { Taxon }\end{array}$} & \multicolumn{4}{|c|}{ Metabolic parameter $(y)$ as a function of total body wet weight $(M), y=a M^{v}$} \\
\hline & $a$ & $b( \pm 95 \% \mathrm{CI}, \mathrm{n})$ & $\mathrm{p} \leq$ & $\mathrm{R}$ \\
\hline \multicolumn{5}{|c|}{ Oxygen consumption rate ( $\mu \mathrm{mol} \mathrm{g} \mathrm{g}^{-1} \mathrm{~h}^{-1}$ ) } \\
\hline All Copepoda & 0.654 & $-0.214(0.132,170)$ & 0.0017 & 0.331 \\
\hline Augauptilidae & 0.015 & $-1.055(0.667,22)$ & 0.0036 & 0.567 \\
\hline Heterorhabdidae & 0.009 & $-1.121(0.638,17)$ & 0.0019 & 0.759 \\
\hline Aetideidae & 0.062 & $-0.814(0.526,14)$ & 0.0053 & 0.745 \\
\hline Euchaetidae & 0.227 & $-0.529(0.280,30)$ & 0.0006 & 0.590 \\
\hline \multicolumn{5}{|c|}{ Citrate synthase activity (units $\mathrm{g}^{-1}$ ) } \\
\hline All Copepoda & 4.807 & $0.347(0.165,223)$ & 0.0001 & 0.292 \\
\hline Heterorhabdidae & 41.119 & $0.845(0.542,18)$ & 0.0055 & 0.625 \\
\hline \multicolumn{5}{|c|}{ Lactate dehydrogenase activity (units $\mathrm{g}^{-1}$ ) } \\
\hline All Copepoda & 17.973 & $0.404(0.335,226)$ & 0.0182 & 0.186 \\
\hline Augauptilidae & 8.722 & $1.489(0.770,25)$ & 0.0006 & 0.640 \\
\hline Heterorhabdidae & 13.938 & $2.477(0.650,18)$ & 0.0001 & 0.896 \\
\hline Euchaetidae & -2.036 & $-0.474(0.409,36)$ & 0.0184 & 0.391 \\
\hline Megacalanidae & 10.580 & $2.870(1.042,58)$ & 0.0001 & 0.595 \\
\hline \multicolumn{5}{|c|}{ Protein content ( $\%$ wet weight) } \\
\hline All Copepoda & 0.268 & $-0.592(0.157,136)$ & 0.0001 & 0.542 \\
\hline Augauptilidae & 0.107 & $-0.734(0.660,19)$ & 0.0315 & 0.494 \\
\hline Megacalanidae & 0.020 & $-1.424(0.427,35)$ & 0.0001 & 0.763 \\
\hline
\end{tabular}

5.947 units $\mathrm{g}^{-1}$ and mean LDH activities ranged from 0.086 to 70.027 units $\mathrm{g}^{-1}$ The metabolic poise of over half the species was anaerobic, but 12 species had lower LDH actives than CS activities. The Euchaetidae and Augauptilidae showed significant relationships of $\mathrm{LDH}$ activity with increasing body mass (Fig. 5A, B, Table 2). Protein content (\% wet weight) showed a strong decline with increasing body mass (Fig. 6).

Gaussia princeps males had higher LDH activities than did females (unpaired, 2-tailed $t$-test, $t=7.37, \mathrm{p}=$ 0.0001 ). Male specimens of $G$. princeps were significantly smaller on average than females, with mean weights of 0.0335 and $0.0368 \mathrm{~g}$, respectively (unpaired, 2 -tailed $t$-test, $t=3.06, p=0.0075$ ). However, male and female weight ranges did overlap (Table 1). Oxygen consumption rates, $\mathrm{CS}$ activities and protein contents were not significantly different between the 2 sexes of G. princeps.

None of the biochemical parameters were particularly good predictors of metabolic rate. Although linear regressions of LDH activity and protein content against oxygen consumption were statistically significant ( $\mathrm{p}=$ 0.0001 for both). $\mathrm{R}^{2}$ values for the relationships were low at 0.215 and 0.189 , respectively. CS activity was not significantly correlated with metabolic rate.

\section{Depth-related changes}

When compared with the rates of shallow-living species (Champalbert \& Gaudy 1972, Gaudy 1975) that have been adjusted for temperature using a $Q_{10}$ of 2 and size-corrected to wet weight of $10 \mathrm{mg}$, metabolic rates of deep-sea copepods do not display a decline with increasing capture depth (Fig. 7). The results of an ANCOVA show that the depth-related trend is significantly different from that displayed by other pelagic crustaceans $(\mathrm{p}<0.005)$.

\section{DISCUSSION}

Studies on the metabolic biochemistry and oxygen consumption of deep-sea copepods can provide insight regarding their biology and ecology. Of particular interest is whether or not these organisms have evolved metabolic characteristics that correspond to specialized behavioural niches or habitat depth.

\section{Oxygen consumption rates}

Large intra-specific, as well as inter-specific, variations exist in the oxygen consumption rates of copepods. Our respiration measurements of Euaugaptilus magnus are in close agreement with those made by Champalbert \& Gaudy (1972) off the Canary Islands for E. magnus, but our measurements for Gaetanus kruppi are an order of magnitude higher than Champalbert \& Gaudy (1972) found for the same species. The metabolic rates we measured for $G$. kruppi are very similar to the higher rates measured by Gaudy 

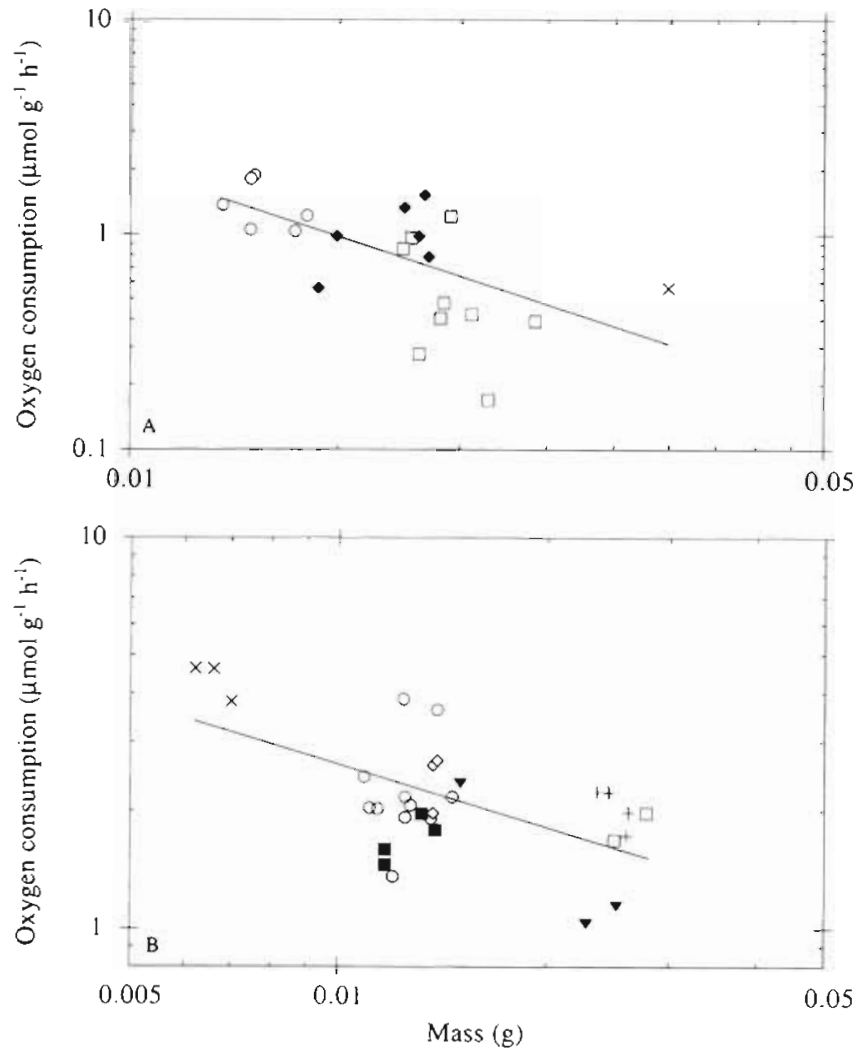

Fig. 2. Oxygen consumption rates ( $\mu \mathrm{mol} \mathrm{O}_{2} \mathrm{~g}^{-1}$ wet weight $\mathrm{h}^{-1}$ ) of specific taxonomic groups of copepods with respect to body mass. (A) All Augauptilidae: the slope of the regression line is $y=0.015 x^{-1055}, R=0.567, p<0.004$. Euaugaptilus antarcticus ( $\bullet$ ), E. magnus (口), E. nodifrons $(x)$, and Pachyptilus pacificus (O). (B) All Euchaetidae: Paraeuchaeta birostrata $(0)$, . californica $(\diamond)$, P. rubra (匹), P. sesquipedalis (+), $P$. tonsa $(x)$, Pseudeuchaeta brevicauda ( $\square)$, Valdiviella oligarthra ( $\mathbf{v}$ ). The equation of the regression line is $y=$ $0.227 x^{-0.529}, R=0.590, p<0.001$

(1975) for this species in the Mediterranean Sea. The metabolic rate of Paraeuchaeta tonsa that we measured in California is similar to that of Paraeuchaeta gracilis in the Mediterranean Sea presented by Gaudy (1975). Childress (1977) previously measured the metabolic rates of Gaussia princeps males, and, although we used a different technique in this study, the oxygen consumption rates we measured for $G$. princeps agree well with those of Childress (1977).

The range in energy usage between resting and active metabolism, or metabolic scope, could play a role in the variation of metabolic rates measured in our study if some of the specimens were more active than others during incubations. Metabolic costs of swimming in small crustaceans have usually been considered to be very small (see Morris et al. 1985 for a review). However, Morris et al. (1985) predicted that the metabolic scope for copepods would be greater than a factor of 3 based on a hydromechanical model.
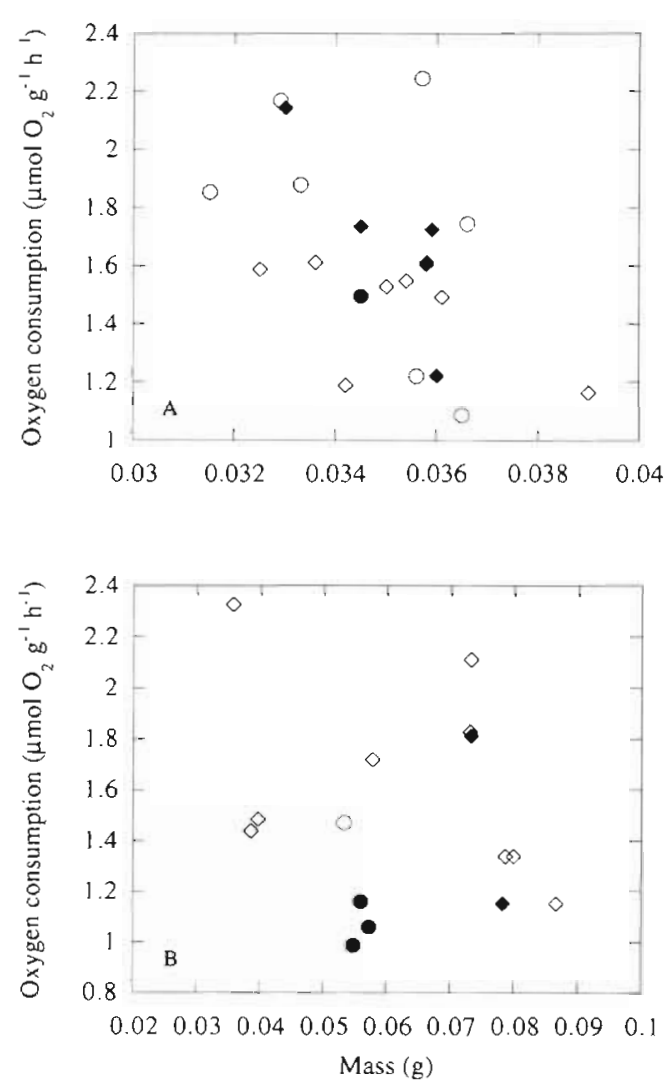

Fig. 3. (A) Oxygen consumption rates of Megacalanus sp. A measured at $1 \mathrm{~atm}$ at $1.5^{\circ} \mathrm{C}(0)$ and $5^{\circ} \mathrm{C}(0)$ and 101 atm at $1.5^{\circ} \mathrm{C}(\bullet)$ and $5^{\circ} \mathrm{C}(\bullet)$. There is no significant difference in oxygen consumption at $1.5^{\circ} \mathrm{C}$ between the 2 pressures (2-tailed $t$-test, $t=1.612, \mathrm{p}=0.138$ ) and no apparent difference at $5^{\circ} \mathrm{C}$. Including all data taken at both pressures, there is not a significant difference between the oxygen consumption measurements made at $1.5^{\circ} \mathrm{C}$ and $5^{\circ} \mathrm{C}(2$-tailed $t$-test, $t=$ 1.092, $\mathrm{p}=0.288$ ), although the mean values are lower at the lower temperature (mean $\pm \mathrm{SE}$ of $1.550 \pm 0.072$ and $1.711 \pm$ $0.418 \mu \mathrm{mol} \mathrm{g} \mathrm{g}^{-1} \mathrm{~h}^{-1}$, respectively). (B) Oxygen consumption rates at $5^{\circ} \mathrm{C}$ of Bathycalanus bradyi and Bathycalanus richardi measured at $1 \mathrm{~atm}[B . \operatorname{brady}(\diamond), B$. richardi $(0)]$ and $101 \mathrm{~atm}$ $[B$ bradyi $(\bullet), B$ richardi $(\bullet)]$. No apparent differences in oxygen consumption can be discerned in this data set

Recently, Buskey (1998) measured the metabolic scope of Dioithona oculata from mangrove habitats in Belize. He found that the metabolic rate of $D$. oculata during active swimming was about 3 times that measured during normal swimming and potentially 7 times that of $D$. oculata at rest, thereby agreeing with the predictions of the Morris et al. (1985) hydromechanical model. This model and Buskey's (1998) experimental evidence suggest a larger metabolic scope for copepods than traditionally estimated and illustrates the need for considering the metabolic cost of swimming in studies of zooplankton community metabolism. The variation in oxygen consumption between closely related species (e.g. the Augauptilidae) can also be very high, demon- 

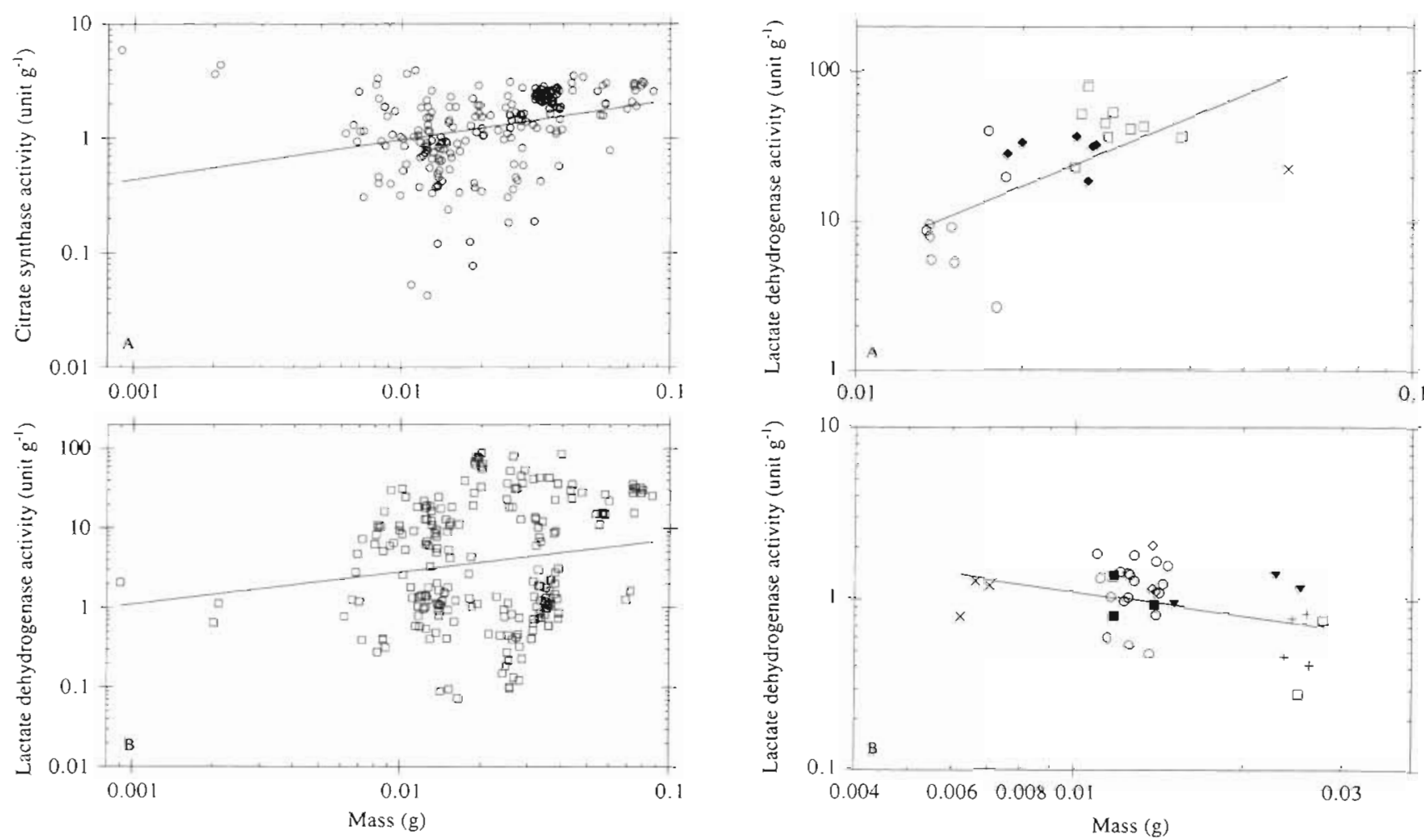

Fig. 4. Relationship between body size ( $g$ wet weight) and mass-specitic enzymatic activities in deep-sea copepods. The equation of the regression line for the citrate synthase (CS) data (A) is $y=4.807 x^{0.347}, R=0.292, p=0.0001$. The equation of the regression line for the lactate dehydrogenase (LDH) data $(B)$ is $y=17.973 x^{0404}, R=0.186, p=0.0182$

strating that taxonomic differences are also very important in calculations of zooplankton community metabolism.

There are large variations in the effect of temperature on metabolic rates of copepods and our data on temperature effects are similar to those presented previously. That is, there can be practically no effect of temperature or very large effects (Champalbert \& Gaudy 1972, Ikeda 1974, Gaudy 1975, Childress 1977. Hiromi et al. 1988). Clearly, this is an area in need of further investigation. Our results showing that the respiration rates of megacalanid copepods are relatively unaffected by hydrostatic pressure agrees with the established paradigm that respiration rates of midwater animals show little, if any, change in metabolic rates when measured within, or somewhat outside, the range of pressures experienced in their natural environment (Childress \& Thuesen 1993).

The metabolic scaling of the copepods in our study is unclear. Although the 2 smallest individuals had the highest metabolic rates and the scaling coefficient is normal ( $b=-0.21)$, there is considerable scatter in the data $\left(R^{2}=0.11\right)$. The differences in metabolic rates

Fig. 5. Lactate dehydrogenase activities of specific taxonomic groups of copepods with respect to body mass. (A) All

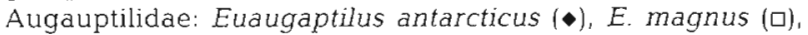
$E$. nodifrons $(x)$, and Pachyptilus pacificus ( 0 ). The equation of the regression line is $y=8.722 x^{1.489}, R=0.640, p=0.0006$. (B) All Euchaetidae: Paraeuchaeta birostrata (O), P. californica $(0)$, P. rubra ( $)$, P. sesquipedalis $(+), P$. tonsa $(x)$, Pseudeuchaeta brevicauda (ם). Valdiviella oligarthra ( $\mathbf{v})$. The equation of the regression line is $y=-2.036 x^{-0474}, \mathrm{R}=0.391, \mathrm{p}=$ 0.01843

between taxonomic groups are greater than can be explained by the effects of size alone, and phylogenetic history may play a part in the variation of our data (cf. Harvey \& Pagel 1991).

\section{Enzymatic variation}

Two other studies have investigated the activities of citrate synthase and lactate dehydrogenase of copepods. Flint et al. (1991) measured LDH in Eucalanus inermis and Eucalanus elongatus in the eastern Tropical Pacific, but could not detect any LDH activity in Eucalanus subtenuis, Calanus pacificus, Calanus australis or Rhincalanus nasutus. The LDH activities they measured for eucalanids are 5 to 10 times higher than those we measured for $C$. pacificus. We measured LDH activities without difficulty in $C$. pacificus collected off California, and we do not know why they were not able to find any LDH activity in this species from the 


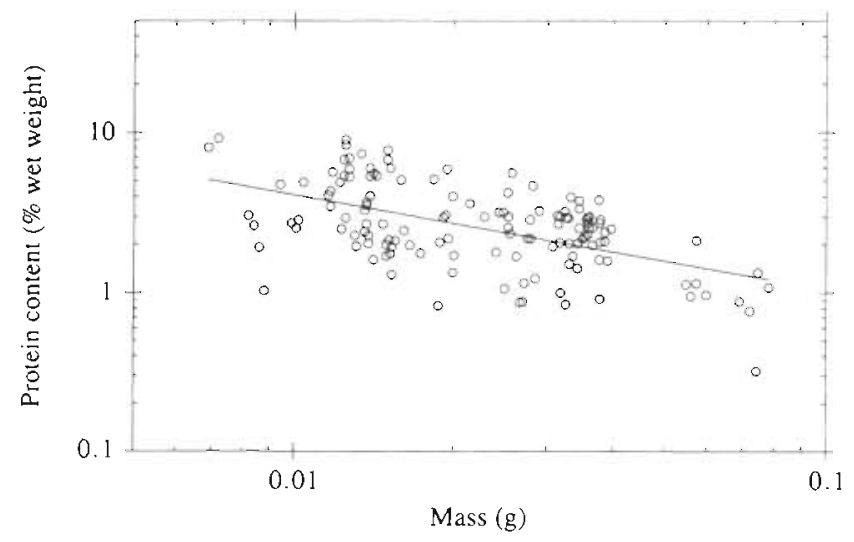

Fig. 6. Relationship between body size ( $g$ wet weight) and protein content ( $\%$ wet weight) in deep-sea copepods. The equation of the regression line is $y=0.268 x^{-0.592}, R=0.542$, $\mathrm{p}=0.0001$

eastern Tropical Pacific. They suggested that higher levels of LDH allowed the eucalanids to survive in the pronounced oxygen minimum layer of the eastern Tropical Pacific. The majority of the species investigated in our study were anaerobically poised, with higher LDH activities than CS activities, suggesting that glycolytic energy is very important in these copepods. Clarke \& Walsh (1993) measured the activities of CS in Acartia tonsa and Temora longicornis. They were unable to detect $\mathrm{LDH}$ in $A$. tonsa. It would appear, based on these 2 studies and our own results, that small epipelagic copepods, such as C. pacificus, have less reliance on glycolytic energy sources than do mesopelagic and bathypelagic copepods. This glycolytic energy could be used during burst swimming, as a supplemental source of energy during extensive vertical migrations through the water column or during extended stays in low oxygen zones. The statistically significant increases in weight-specific activities of CS and LDH as a function of body mass (Fig. 4) have very low correlation coefficients, indicating that factors other than size are helping to determine enzymatic activities.

Our results clearly show that the amount of $\mathrm{LDH}$ activity (glycolytic potential) relative to CS activity (putative indicator of aerobic metabolism) is distinct for each of the 33 species (Fig. 8). We interpret this as a reflection of the different morphology and behaviour (swimming, feeding, reproduction) of each species. Most of this difference is observed in the glycolytic potential of each species. We would expect species that use burst swimming in their search for food or mates to have high LDH activities, while quiescent species would have lower levels of LDH. Slowly cruising predators might have lower LDH activities than sit and wait predators if their use of burst activity is differ- ent. Species which vertically migrate through the oxygen minimum layer would also be likely to need higher LDH activities to support their higher levels of activity during migration. Almost all the copepods in our study are carnivorous or omnivorous, however, they represent a variety of morphological groups.

We observed 3 general metabolic groups among large deep-sea copepods (Fig, 8). Species were divided into groups based on observations of basic morphological patterns and behaviours that were made aboard ship. The species that must swim continuously in captivity to avoid rapid sinking have relatively low $\mathrm{LDH}$ levels. These 'muscular sinkers' include the members of the superfamily Clausocalanoidea (e.g. Onchocalanus magnus, Gaetanus antarcticus, G. kruppi and $G$. pileatus). They have little reliance on glycolytic activity for swimming and a more limited burst escape ability. Another group of copepods in our study had thin muscles and hung still and suspended in collection containers, partly supported by long, supple setae on 1 or more limbs or the urosome. These 'thin-muscled floaters', mostly members of the Augaptiloidea, have high LDH activities. They presumably are sit and wait predators. The third metabolic group we refer to as the 'giants' and it includes Megacalanus spp., Bathycalanus spp. and Gaussia princeps. These copepods have very large bodies and are fairly muscular They all have roughly the same CS levels, but they display a large range of $\mathrm{LDH}$ activities. We know very little about the biology of the megacalanid species other

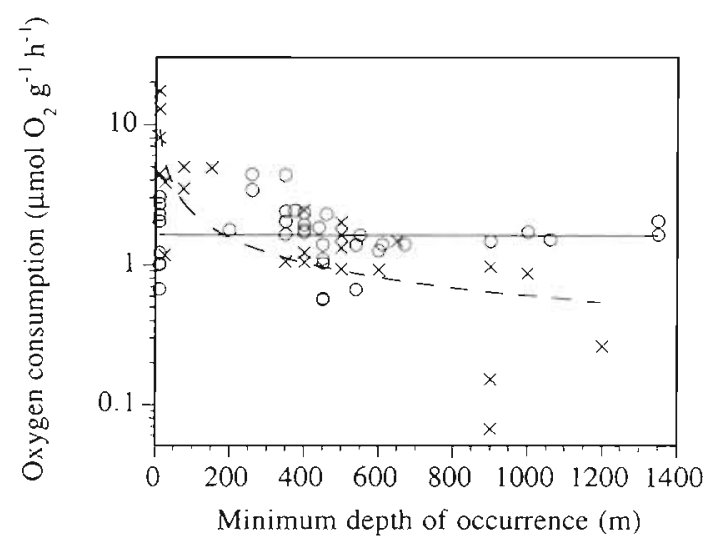

Fig. 7. Metabolic rates of copepods (o) and crustaceans $(x)$ with respect to habitat depth. Rates of shallow-living species are from Champalbert \& Gaudy (1972) and Gaudy (1975) and have been adjusted for temperature using a $Q_{10}$ of 2 and sizecorrected to a wet weight of $10 \mathrm{mg}$ using a scaling coefficient of -0.214 (see Fig. 1). No copepods are included in the crustacean data from Childress (1975). The equation of the regression line for the copepod data is $y=1.652 x^{-0.003}, \mathrm{R}=$ $0.049, p=0.68$. The equation of the regression line for the crustacean data is $y=35.936 x^{-0.593}, \mathrm{R}=0.811, \mathrm{p}=0.0001$. ANCOVA shows that slopes of the regressions are significantly different from each other, $\mathrm{p}<0.005$ 


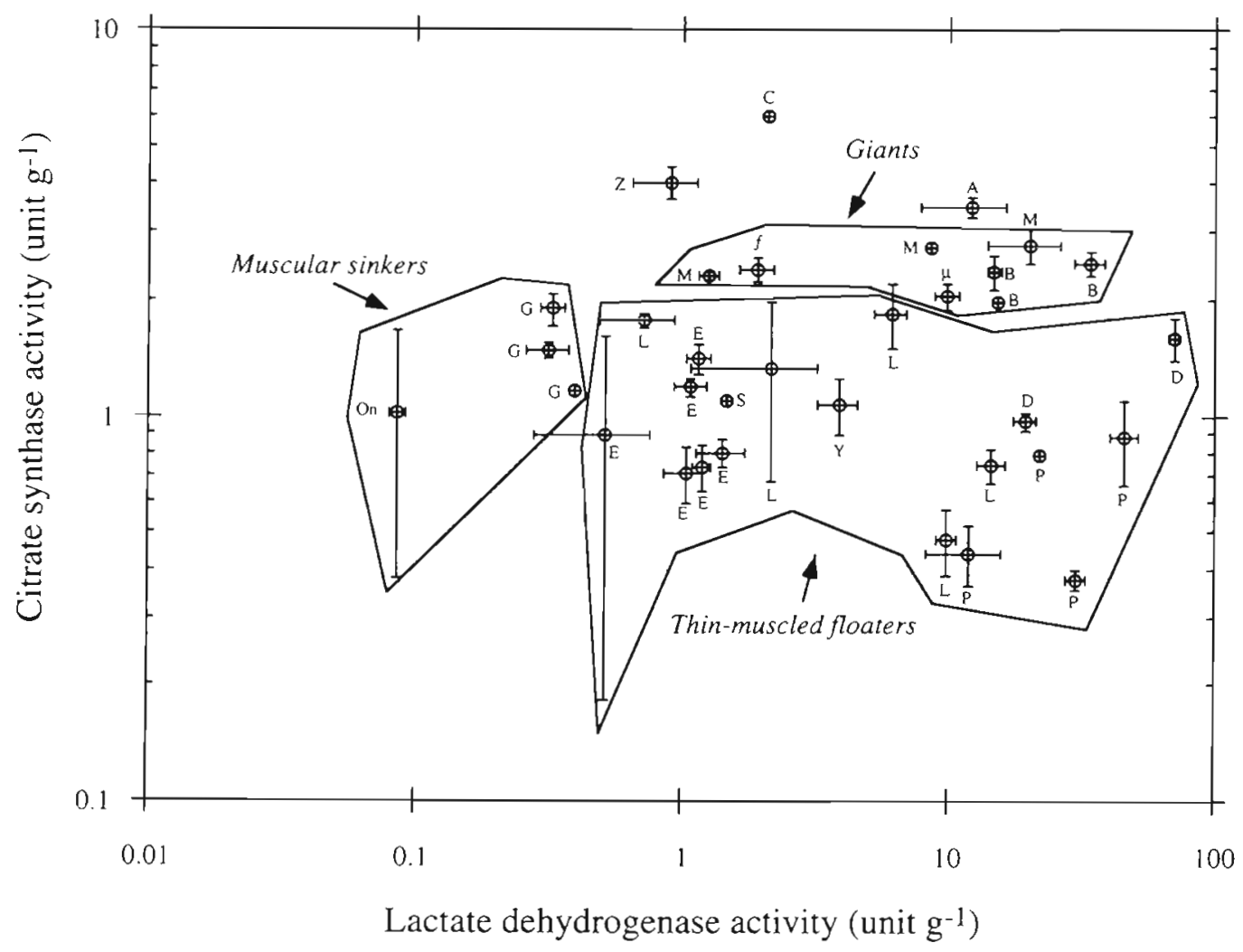

Fig. 8. Relationship between mean ( \pm SE) citrate synthase activities and mean $( \pm$ SE) lactate dehydrogenase activities in copepods. Data are from Table 1. The 3 metabolic groups, 'muscular sinkers', 'thin-muscled floaters' and 'giants', relate to morphological pattern and behaviour (see 'Discussion'). A: Arietellus plumifer; B: Bathycalanus spp.; C: Calanus pacificus; D: Heterorhabdidae; E: Euchaetidae; G: Gaetanus spp.; L: Lucicitidae; M: Megacalanus spp.; On: Onchocalanus magnus; P: Augauptilidae: S: Landrumius gigas; Y: Metridia princeps; Z: Pleuromamma abdominalis; $f$. Gaussia princeps females; $\mu$ : $G$. princeps males

than that they are deep-living and likely feed on detritus. One species which has characteristics of both the 'muscular sinkers' and the 'thin-muscled floaters' is Arietellus plumifer. This augaptiloid copepod has big fans for hanging still in the water, lots of muscles, an elaborate array of setae armed with recurved hooks for prey capture, and a demonstrated capacity for sustained swimming in the sample containers aboard ship. It has one of the highest levels of CS and lots of $\mathrm{LDH}$, apparently allowing it to adopt either metabolic style. Fig. 8 demonstrates that our observations of morphology and behaviour made aboard ship correspond in an interpretable way with the biochemical patterns observed in the laboratory, and we expect that these observations reflect actual in situ ecological roles.

Some copepods likely rely on anaerobic metabolism in both anoxic freshwater environments and lowoxygen marine environments (Shapiro 1960, Chaston 1969, Childress 1977), but there have been no specific investigations of the biochemical adaptations of copepods to anoxic conditions. Both Gaussia princeps males and females are known to inhabit the oxygen minimum layer, but males have average LDH activities that are about 5 times the LDH activities of females. Males of $G$. princeps can survive anoxia for over 10 to $14 \mathrm{~h}$ and are not able to live aerobically within the oxygen minimum layer off California (Childress 1977). Do the high LDH activities of $G$. princeps males indicate that these copepods are utilizing glycolytic energy during their stay in the oxygen minimum layer? We know of no correlation between the LDH activities of crustaceans and anaerobic survival. LDH activities should reflect burst locomotion abilities, whereas survival at low oxygen concentrations should be more closely related to buffering ability and substrate stores. In other words, even copepods with low LDH activities may be using LDH for anaerobic survival, but they must have the appropriate substrate levels and the capacity to buffer the endproducts of glycolysis. Perhaps, males of $G$. princeps have higher LDH activities than females because they are utilizing glycolytic power during mating.

Lucicutia grandis has been reported to be an inhabitant of the eastern Tropical Pacific oxygen minimum layer (Wishner et al. 1995), and the 2 species of Lucicutia in our study had fairly high LDH activities. Since 
larger species of pelagic organisms can be excluded from the oxygen minimum layer (Childress 1975), it is possible that LDH activities would be higher in larger species if high LDH activities are an adaptation to the oxygen minimum layer. Positive scaling of $\mathrm{LDH}$ as observed for these copepods could be interpreted as such an adaptation, but the largest megacalanid copepod in our study, Bathycalanus bradyi, lives below the layer of lowest oxygen concentration. Positive scaling relationships of LDH in other aquatic organisms have been interpreted as adaptations to burst swimming (Childress \& Somero 1990). Calanoid copepods have well-developed hearts with good circulation of blood to the major body parts (Lowe 1935, Park 1966), but they have no known oxygen binding proteins. The ability to utilize glycolytic energy during periods of low oxygen availability would greatly enhance their ability to live in these environments. However, our data do not fully support the suggestion that high LDH activities are adaptations to low oxygen concentrations, and other biochemical factors must be in effect.

We were unable to show that CS was significantly correlated with oxygen consumption in these copepods. This is disappointing since one of our goals in this study was to develop an index for predicting metabolic rates from CS activities. In addition to phylogenetic differences and effects of metabolic scope, it is possible that nutritional status could contribute to differences in metabolic enzyme activity levels (RocheMayzaud et al. 1991, Clarke \& Walsh 1993, Mayzaud et al. 1994, J. B. Company \& E. V. Thuesen unpubl.). However, not all studies have shown correlations of diet or growth rate with enzyme activity level (Berges et al. 1993). Reproductive state of copepods could also play a role in the relative activities of metabolic enzymes. Given large variations in metabolic rates and enzymatic activities, it is apparent that enzymes of copepods are going to be difficult to use as predictors of oxygen consumption rates in copepods.

\section{Comparisons with other pelagic organisms}

The range of mean metabolic rates measured for deep-sea copepods, 0.563 to $4.344 \mu \mathrm{mol} \mathrm{O} \mathrm{O}^{-1} \mathrm{~h}^{-1}$, encompasses that of many other deep-sea pelagic organisms at the same temperature from the same study area off California (Thuesen \& Childress 1993a, b, 1994, E. V. Thuesen, J. J. Childress, M. T. Biondi \& C. B. Miller unpubl.). Most gelatinous organisms have metabolic rates that are at the lower end of or below the metabolic rates of copepods. Metabolic rates of chaetognaths are in the middle to lower end of the copepod range. Some tomopterid worms have metabolic rates higher than the highest copepod metabolic rates in our study. Halocyprid ostracods have metabolic rates similar to those of the highest we measured for copepods (Thuesen et al. unpubl.), and the pelagic ostracod Conchoecia valdiviae has higher LDH activities than any of the copepods in this study, although its CS activities are similar (Thuesen et al. unpubl.). Specific knowledge regarding the metabolic potential of copepods to transform carbon in the deep sea, relative to that of other groups of zooplankton, is necessarily dependent on the species composition of the pelagic community. Metabolic information at the genus or species level, combined with corresponding biomass data, is necessary in order to predict accurately the metabolic carbon flux of midwater organisms.

The metabolic rates of visually orienting shrimps, fishes and cephalopods decline with increasing habitat depth (Childress 1975, Torres et al, 1979, Seibel et al. 1997). However, the metabolic rates of chaetognaths and medusae are independent of depth of occurrence (Thuesen \& Childress 1993, 1994). Do the metabolic rates of copepods decline with increasing depth of occurrence? Although it has previously been suggested that neustonic pontellid copepods have higher rates than surface calanid copepods, this is not generally supported (see review by Champalbert 1985). Despite the limited data on the depth distributions of the copepods in our investigation, we suggest that the metabolic rates of copepods do not decline dramatically with increasing habitat depth (Fig. 7). The deepsea copepods in our study generally have metabolic rates similar to, or somewhat lower than, the rates of shallower-living copepods presented by other investigators (e.g. Champalbert \& Gaudy 1972, Ikeda 1974 , Gaudy 1975). After accounting for the effects of size and temperature, there is not a significant difference between the metabolic rates of shallow-living and deep-sea copepods. Our observations on copepods are consistent with the visual interactions hypothesis 'see review by Childress 1995). That is, as visual rarges shorten with increasing depth in the sea, the required locomotory abilities and both actual and potential metabolic rates of visually-orienting organisms also decline, even after accounting for the effects of colder temperature. In contrast, predators locating prey either by chance touching (e.g. cnidarians) or by vibratory stimuli (e.g. chaetognaths) have no comparable shortening of detection range with depth, and there is no depth-related decline in their metabolic rates beyond that which can be accounted for by decreasing temperature. Copepods do not detect either prey or predators visually, so their required range of reaction does not shorten with increasing habitat depth. Hence, copepods do not display the very large depth-related declines in metabolic rates that are found in shrimps, fishes and cephalopods. 
Acknowledgements. We thank the captains, crews and scientists aboard the RV 'Point Sur' and RV 'New Horizon' for their assistance at sea. Drs J. Bradford and T Park kindly assisted with identification of many copepod species, K. D. McCullough, P. Newell and M. T Biondi assisted with analyses of enzymatic activities, and B. Seibel provided valuable comments on the manuscript. This research was supported through NSF grants OCE-9115551 and OCE-9415543 to J.J.C. and OCE-9012295 to C.B.M.

\section{LITERATURE CITED}

Angel $M(1989)$ Does mesopelagic biology affect the vertical flux? In: Berger WH, Smetacek VS, Wefer G (eds) Productivity of the ocean present and past. John Wiley and Sons Limited. Chichester, p 155-173

Berges JA, Ballantyne JS (1991) Size scaling of whole-body maximal enzyme activities in aquatic crustaceans. Can J Fish Aquat Sci 48:2385-2394

Berges JA, Roff JC, Ballantyne JS (1993) Enzymatic indices of respiration and ammonia excretion: relationships to body size and food levels. J Plankton Res 15:239-254

Buskey EJ (1998) Energetic costs of swarming behavior for the copepod Dioithona oculata. Mar Biol 130:425-531

Champalbert G (1985) L'hyponeuston permanent. Approche ecophysiologique de la repartition des Pontellidae (Crustacea, Copepoda). Téthys 11:264 -274

Champalbert G, Gaudy R (1972) Etude de la respiration chez des copépodes de niveaux bathymétriques varies dans la région sud marocaine et canarjenne. Mar Biol 12:159-169

Chaston I (1969) Anaerobiosis in Cyclops varicans. Limnol Oceanogr 14:298-301

Childress JJ (1971) Respiratory rate and depth of occurrence of midwater animals. Limnol Oceanogr 16:104-106

Childress JJ (1975) The respiratory rates of midwater crustaceans as a function of depth occurrence and relation to the oxygen minimum layer off Southern California. Comp Biochem Physiol 50A:787-799

Childress JJ (1977) Effects of pressure, temperature and oxygen on the oxygen consumption rate of the midwater copepod Gaussia princeps. Mar Biol 39:19-24

Childress JJ (1995) Are there physiological and biochemical adaptations of metabolism in deep-sea animals? Trends Ecol Evol 1.0:30-36

Childress JJ, Arp AJ, Fisher CR Jr (1984) Metabolic and blood characteristics of the hydrothermal vent tube worm Riftia pachyptila. Mar Biol 83:109-124

Childress JJ, Barnes AT, Quetin LB, Robison BH (1978) Thermally protecting cod ends for recovery of living deep-sea animals. Deep Sea Res 25:419-422

Childress JJ, Mickel TJ (1980) A motion compensated shipboard precision balance system. Deep Sea Res 27A: 965-970

Childress JJ, Nygaard MH (1974) The chemical composition and relative buoyancy of midwater crustaceans as a function of depth off Southern California. Mar Biol 27:225-238

Childress JJ, Somero GN (1979) Depth related enzymic activities in muscle, brain and heart of deep-living pelagic marine teleosts. Mar Biol 52:273-283

Childress JJ, Somero GN (1990) Metabolic scaling: a new perspective based on scaling of glycolytic enzyme activities. Am Zool 30:161-173

Childress JJ, Thuesen EV (1992) Metabolic potentid of deepsea animals: regional and global scales. In: Rowe GT, Pariente $V$ (eds) Deep-sea food chains and the global carbon cycle. Kluwer Academic Publishers, Dordrecht, p 21.7-236
Childress JJ, Thuesen EV (1993) Effects of hydrostatic pressure on metabolic rates of six species of deep-sea gelatinous zooplankton. Limnol Oceanogr 38.665-670

Clarke ME. Walsh PJ (1993) Effect of nutritional status on citrate synthase activity in Acartia tonsa and Temora longlcornis. Limnol Oceanogr 38:414-4.18

Flint MV, Drits AV, Pasternak AF (1991) Characteristic features of body composition and metabolism in some interzonal copepods. Mar Biol 111:199-205

Gaudy R (1975) Etude de la respiration chez des copépodes pélagiques méditeranéens (bassin occidental et Mer Ionienne) et de ses variations en fonction de la bathymétrie des espèces et de leur origine géographique. Mar Biol 29: $109-118$

Harvey $\mathrm{PH}_{1}$ Pagel MD (1991) The comparative method in evolutionary biology. Oxford University Press, New York

Hiromi J, Nagata T, Kadota S (1988) Respiration of the small planktonic copepod Oithona davisae at different temperatures. Bull Plankton Soc Jpn 35:143-148

Ikeda T (1974) Nutritional ecology of marine zooplankton. Mem Fac Fish Hokkaido Univ 22:1-97

Lee RF, Barnes AT (1975) Lipids in the mesopelagic copepod Gaussa princeps. Wax ester utilization during starvation. Comp Biochem Physiol 52B:265-268

Lee RF, Hirata J, Barnett AM (1971) Distribution and importance of wax esters in marine copepods and other zooplankton. Deep Sea Res 18:1147-1165

Longhurst AR, Bedo AW, Harrison WG, Head EJH, Sameoto DD (1990) Vertical flux of respiratory carbon by oceanic diel migrant biota. Deep Sea Res 37:685-694

Lowe $\mathrm{E}$ (1935) On the anatomy of a marine copepod, Calanus finmarchicus. Trans R Soc Edinb 58:561-603

Lowry OH, Roseborough NJ, Farr AL, Randall RJ (1951) Protein measurement with the folin phenol reagent. J Biol Chem 193:265-275

Mayzaud P, Biggs DC, Roche-Mayzaud O (1994) Short-term variability of metabolic and digestive enzyme activity in naturally occurring populations of adult copepod Acartia clausi. Écoscience 1:195-207

Morris MJ, Gust G, Torres JJ (1985) Propulsion efficiency and cost of transport for copepods: a hydromechanical model of crustacean swimming. Mar Biol 86:283-295

Park T (1966) The biology of a calanoid copepod Epilabidocera amphitrites McMurrich. Cellule 66:129-251

Roche-Mayzaud O, Mayzaud P, Biggs DC (1991) Meduumterm acclumation of feeding and of digestive and metabolic enzyme activity in the neritic copepod Acartia clausi. I. Evidence from laboratory experiments. Mar Ecol Prog Ser 69:25-40

Seibel BA, Thuesen EV, Childress JJ, Gorodezky LA (1997) Decline in pelagic cephalopod metabolism with habitat depth reflects differences in locomotory efficiency. Biol Bull 192:262-278

Shapiro J (1960) The cause of a metalimnetic minimum of dissolved oxygen. Limnol Oceanogr 5:216-227

Somero GN, Childress JJ (1980) A violation of the metabolism-size scaling paradigm: activities of glycolytic enzymes in muscle increase in larger-size fish. Physiol Zool 53:322-337

Somero GN, Childress JJ (1990) Scaling of ATP-supplying enzymes, myofibrillar proteins and buffering capacity in fish muscle: relationship to locomotory habit. $J$ Exp Biol 149:319-333

Sullivan KM, Somero GN (1980) Enzyme activities of fish skeletal muscle and brain as influenced by depth of occurrence and habits of feeding and locomotion Mar Biol 60: $91-99$ 
Thuesen EV, Childress JJ (1993a) Enzymatic activities and metabolic rates of pelagic chaetognaths: lack of depthrelated declines. Limnol Oceanogr 38:935-948

Thuesen EV, Childress JJ (1993b) Metabolic rates, enzyme activities and chemical compositions of some deep-sea pelagic worms, particularly Nectonemertes mirabilis (Nemertea; Hoplonemertinea) and Poeobius meseres (Annelida; Polychaeta). Deep Sea Res 40:937-951

Thuesen EV, Childress JJ (1994) Oxygen consumption rates and metabolic enzyme activities of oceanic California medusae in relation to body size and habitat depth. Biol

Editorial responsibility: Otto Kinne (Editor), Oldendorf/Luhe, Germany
Bull 187:84-98

Torres JJ, Belman BW, Childress JJ (1979) Oxygen consumption rates of midwater fishes as a function of depth of occurrence. Deep Sea Res 26A:185-197

Torres JJ, Somero GN (1988) Metabolism, enzymic activities and cold adaptation in Antarctic mesopelagic fishes. Mar Biol 98:169-180

Wishner KF, Ashjian CJ, Gelfman C, Gowing MM, Kann L, Levin L, Mullineaux LS, Saltzman J (1995) Pelagic and benthic ecology of the lower interface of the Eastern Tropical Pacific oxygen minimum zone. Deep Sea Res 42:93-115

Submitted: November 11, 1997; Accepted: April 30, 1998

Proofs received from author(s): June 17, 1998 